Energy

Volume 171 Issue EN1

Geothermal energy resources in Oman

Umar
Proceedings of the Institution of Civil Engineers

Energy 171 February 2018 Issue EN1

Pages 37-43 https://doi.org/10.1680/jener.17.00001

Paper 1700001

Received 26/12/2016 Accepted 12/05/2017

Published online 21/06/2017

Keywords: energy/fossil fuels/natural resources

\title{
Geothermal energy resources in Oman
}

Tariq Umar MSc, CEng, MICE

PhD candidate, London South Bank University, London, UK; College of Engineering, A'Sharqiyah University, Ibra, Oman (tariqumar1984@gmail.com)

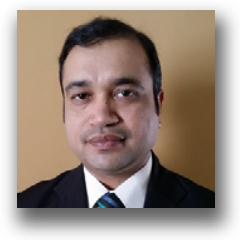

Oman's oil and gas reserves are comparatively low relative to those of other Gulf Co-operation Council member countries. This article explores the potential of using geothermal energy resources for electricity generation in Oman. Geothermal energy is counted as a type of renewable energy, which means its availability is not affected by the lack of source and the increasing price of fossil oil. The review of geothermal energy shows that the cost of electricity generation and the emission of greenhouses gases are comparatively lower than for other forms of renewable energy resources. Different types of geothermal plants are discussed with reference to the required temperature for operation of these plants. Binary cycle geothermal power plants are used for low-temperature applications $\left(85-175^{\circ} \mathrm{C}\right)$. The temperature of 53 boreholes in Oman is more than $100^{\circ} \mathrm{C}$, meaning they can be used in binary geothermal plants for electricity generation. The maximum temperature $\left(173.68^{\circ} \mathrm{C}\right)$ is at Petroleum Development Oman well 'Makarem-I' located in the northern part of Oman. There is opportunity for Oman to adopt renewable energy resources and explore the potential of geothermal in more detail. This will help the country to reduce its dependency on oil and gas and compete in the region towards adopting renewable energy.

\section{Introduction}

Oman's economy is heavily reliant on oil and gas revenues, which in 2014 accounted for about $84 \%$ of the country's export earnings and $47 \cdot 2 \%$ of its gross domestic product (CBO, 2015; NCSI, 2015). All of Oman's domestic energy consumption is supplied by natural gas and oil, reflecting the country's relative abundance of oil and natural gas reserves. In 2011, oil accounted for $71 \%$ of Oman's total primary energy consumption, and natural gas made up the remaining $29 \%$. With the exception of 2009, Oman's petroleum consumption rose steadily over the past decade, reaching 154000 barrels/d in 2013. This makes a further significant contribution towards emissions of greenhouse gases.

Oman, like other Arab gulf countries, depends on oil and gas to produce electricity. However, these resources are not guaranteed to last forever, and are thus one of the energy security issues in the country. Some of the gulf countries have diversified their energy resources; for example, the United Arab Emirates has considered nuclear and renewable energy as part of its electricity generation and Qatar aims to generate $20 \%$ of its energy from renewables by 2024 with $1800 \mathrm{MW}$ of installed green capacity by 2020. As for Oman, the progress of renewable energy development is at a slow pace as currently the electricity generation is still dependent on oil and gas. The Oman Vision 2020 economic development programme seeks to reduce dependence on oil, diversify the economy and create new employment opportunities for all citizens. Oman Vision 2020 also stresses the promotion of technology transfer and the increased use of natural and renewable resources, with due regard to the social and natural environment, which gives priority to the main key aspects (NCSI, 2008).

In the last two decades, energy consumption in the Gulf Cooperation Council (GCC) member countries (Bahrain, Kuwait, Oman, Qatar, Saudi Arabia and the United Arab Emirates) has increased rapidly. In 2013, the average electricity consumption in GCC countries was $\sim 12370.91 \mathrm{kWh} /$ year/capita, while in China this value was 3762.07 (WB, 2016). GCC countries' electricity consumption is more than double the consumption per capita in the UK, which is $5407 \cdot 29 \mathrm{kWh}$. In 2013, the electricity consumption per capita in Oman was $5981.45 \mathrm{kWh}$. The main reason for the high consumption rate of electricity in GCC countries is the high temperature during summer; second, the cost of electricity is very low compared with other countries. The low cost of electricity for both domestic and industrial users in GCC countries does not encourage them to avoid the excessive use of electricity. In Oman, the electricity consumption is comparatively lower than other 
GCC countries as Oman is ahead in terms of infrastructure development and industrialisation.

Umar and Wamuziri (2016) explored the potential of wind and solar energy in Oman and found that there is a huge opportunity to use these resources. This paper provides a review of the geothermal energy resources in Oman by considering the temperature data from Petroleum Development Oman (PDO). Geothermal is derived from the Greek: 'geo' means earth and 'thermal' means heat, and it can be interpreted as geothermal heat or energy produced from the earth. There are 53 boreholes in Oman with temperatures greater than $100^{\circ} \mathrm{C}$, which can be used for electricity generation by way of a binary geothermal energy power plant.

\subsection{Geothermal energy}

Geothermal energy is counted as a type of renewable energy, which means availability is not affected by the lack of source and the increasing price of fossil oil. The energy contained in the geothermal fluid is water, which can be in vapour phase, liquid or as a mixture. The fluid is usually located at a depth of more than $1 \mathrm{~km}$ below the earth's surface. The energy (hot water) comes from the radioactive decay energy from the centre of the earth, where the temperature can reach up to $6650^{\circ} \mathrm{C}$, and this energy moves to the earth's surface by

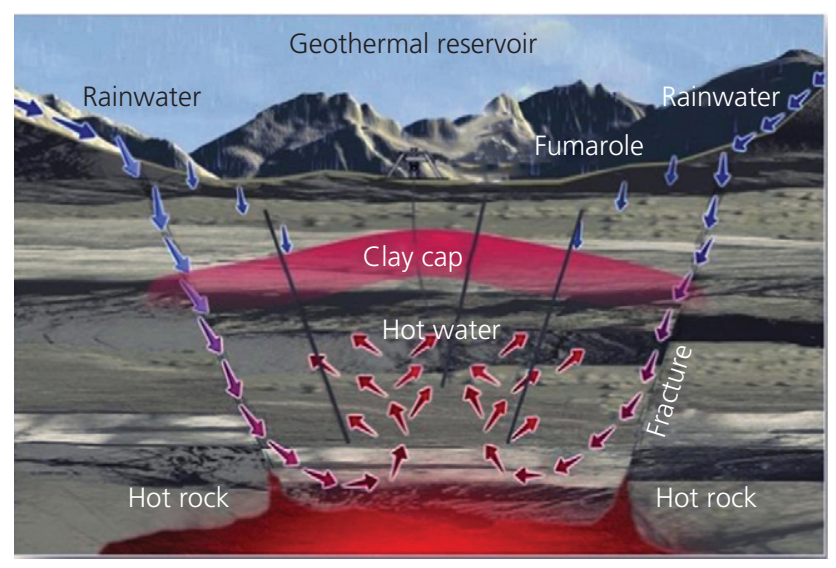

Figure 1. Schematic diagram of the geothermal reservoir (Ngangkham et al., 2012)

Table 1. Categories of geothermal systems (Kaya et al., 2011)

\begin{tabular}{|c|c|c|c|}
\hline Category & & Temperature, $T:{ }^{\circ} \mathrm{C}$ & Production enthalpy, $h: \mathrm{kJ} / \mathrm{kg}$ \\
\hline Hot water & & $T<220$ & $h<943$ \\
\hline \multirow[t]{3}{*}{ Two-phase, liquid-dominated } & Low enthalpy & $220<T<250$ & $943<h<1100$ \\
\hline & Medium enthalpy & $250<T<300$ & $1100<h<1500$ \\
\hline & High enthalpy & $250<T<330$ & $1500<h<2600$ \\
\hline Two-phase, vapour dominated & & $250<T<330$ & $2600<h<2800$ \\
\hline
\end{tabular}

conduction and convection (DiPippo, 2012; Gehringer and Loksha, 2012). It is estimated that the energy flowed from these activities reaches up to 42 million MW. Geothermal energy occurs due to three important elements in a specific location within the earth: source of heat, water and permeable layer (Dickson and Fanelli, 2013). The water comes into the earth from rain or melting snow, is trapped in an impermeable layer and forms the geothermal source, as shown in Figure 1 (Muffler and Cataldi, 1978). Geothermal energy, it is estimated, can supply the need of the world's energy consumption for 100000 years (Sofyan, 2012).

Considering the fluid temperature, the enthalpy of geothermal energy can be classified into low, medium and high. Although sometimes classification can be confusing, at least two variables can be used to determine the thermodynamic state of the water (Lee, 2001). Geothermal classification is still not standardised; some classifications separate geothermal into five categories based on the characteristics of the reservoir. Table 1 lists the characteristics of five geothermal categories: hot water systems; two-phase, liquid-dominated systems with low, medium and high enthalpy; and two-phase, vapour-dominated systems (Kaya et al., 2011). Lower temperatures $\left(120-200^{\circ} \mathrm{C}\right.$ ) require pumping; they are common in extensional terrains, where heating takes place by way of deep circulation along faults, such as in the western USA and Turkey.

In a Rankine cycle binary plant, water passes through a heat exchanger. The water vapourises an organic working fluid that drives a turbine. These binary plants originated in the Soviet Union in the late 1960s and predominate in new US plants. Binary plants have no emissions. Heat pumps extract energy from shallow sources at $10-20^{\circ} \mathrm{C}$ in 43 countries for use in space heating and cooling. Home heating is the fastest growing means of exploiting geothermal energy, with a global annual growth rate of $30 \%$ in 2005 and $20 \%$ in 2012 .

\subsection{Geothermal power plants}

According to Younas et al. (2016) geothermal resources are available in three temperature ranges: $(a)$ low temperature, (b) moderate temperature and (c) high temperature. Above $150^{\circ} \mathrm{C}$ is considered high temperature, while between $90^{\circ} \mathrm{C}$ and $150^{\circ} \mathrm{C}$ is considered moderate and below $90^{\circ} \mathrm{C}$ is considered as low temperature. For different ranges of temperature, 
separate geothermal power plants are used for electric power generation. Geothermal power plants are environmentally friendly, renewable and sustainable due to the characteristics of the energy source (Duffield and Sass, 2003; Holm et al., 2012). The carbon dioxide emission from coal-fired power plants is 12 times more than that from a geothermal power plant, while the carbon dioxide emission from gas power plants is six times more than that from a geothermal power plant (Alhamid et al., 2016). In addition, the area required for a geothermal power plant is smaller than the area required by conventional power plants (Risch and Eastham, 2012). Another advantage of a geothermal power plant is the ability to sustain base load electricity: since the energy produced does not fluctuate with the weather or season, uninterrupted electricity production is possible (Edrisi and Michaelides, 2013; EPRI, 2010).

There are three types of geothermal power plants in use today, namely dry steam, flash steam and binary cycle. The dry type or direct steam power plant (Figure 2) is the typical geothermal plant with a steam vapour-dominated system (dry steam). Dry steam generated from several production wells are circulated by pipes to the turbine. The high-temperature and -pressure steam is used to rotate the turbine. This approach to utilising geothermal energy is restricted because dry-steam hydrothermal resources are very rare.

In a flash steam power plant - also referred to as a wet steam power plant - hydrothermal fluids above $182^{\circ} \mathrm{C}$ can be used to make electricity. Fluid is sprayed into a tank held at a much lower pressure than the fluid, causing some of the fluid to vapourise rapidly, or 'flash'. The vapour then drives a turbine, which drives a generator. If any liquid remains in the tank, it can be flashed again in a second tank to extract even more energy. Flash power plants can be categorised into single-flash and multiple-flash plants. Hot water is collected in a vessel and as water pumps to the generator, water is released from the hot geothermal reservoir and the abrupt change in pressure forces some water to be converted into steam. The steam rotates the turbine and the electrical output is received by generator as presented in Figure 3.

Binary cycle geothermal power plants are used for lowtemperature applications. The hot water heats up another fluid with a low boiling point (BP) - often these are organic compounds, such as butane $\left(\mathrm{BP}=-0 \cdot 5^{\circ} \mathrm{C}\right)$ - by way of a heat exchanger. The steam from this fluid is used to rotate the turbine, which results in electrical output through the generator. The two fluids used in a binary cycle power plant are

geothermal fluid (extracted from a geothermal reservoir)
working fluid (low BP).

The geothermal fluid transfers its energy to the working fluid using a heat exchanger and the working fluid is converted into steam. The steam operates the turbine; steam is then condensed and prepared for the next cycle. The geothermal fluid is sent back to the reservoir for maintaining the internal temperature of the geothermal reservoir. Furthermore, a binary cycle plant operates at temperatures of $85-175^{\circ} \mathrm{C}$. At such temperatures $\left(85-175^{\circ} \mathrm{C}\right)$, substantially less carbon dioxide is

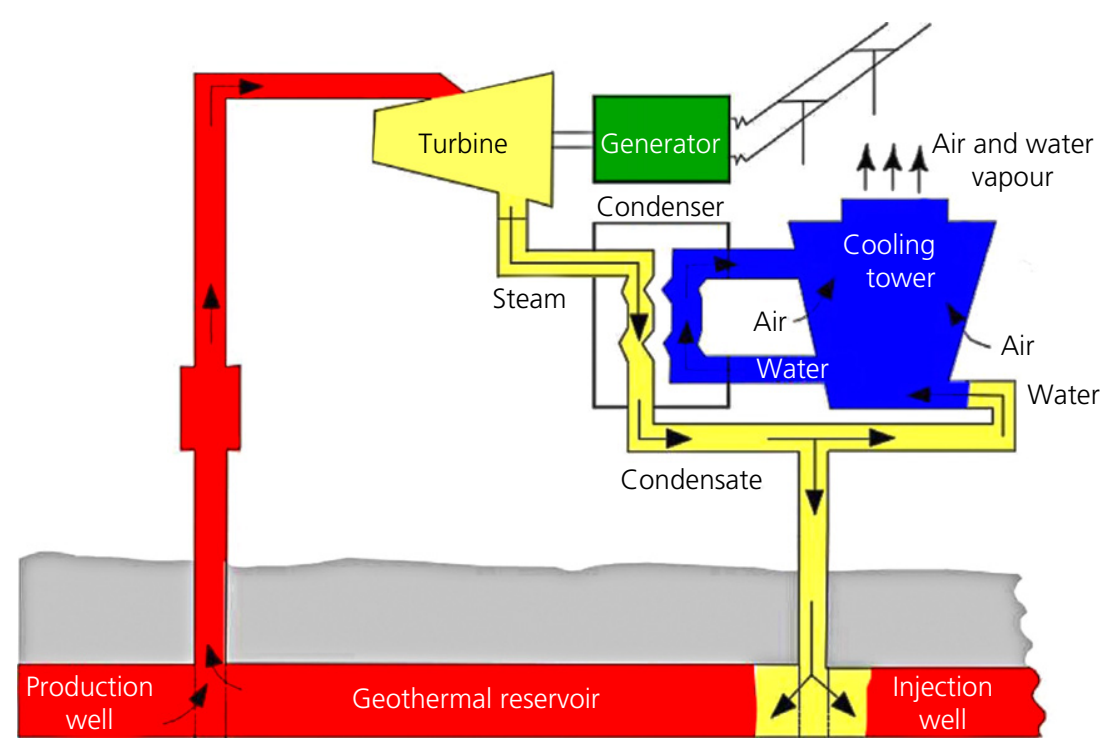

Figure 2. Dry or direct steam power plant (GSE, 2011; Kagel, 2009; Lund, 2009) 
emitted (Kose, 2007). The typical structure of a binary cycle geothermal power plant is shown in Figure 4.

The research conducted by Shevenell (2012) on Nevada geothermal wells reported that a geothermal project's costs might be expected to range from US\$835000 to US $\$ 3.4$ million/MW if the drilling of the well is successful. Similarly, drilling costs per MW were estimated using all drilled wells (successful or not) and the indicated costs could range from US\$341000 to US $\$ 1 \cdot 1$ million/MW. A typical breakdown of costs for the completion of a geothermal power production facility from beginning to end is presented by the Geothermal Energy Association (GEA, 2005) and Hance (2005), and is shown in Figure 5. Although the data presented here are more than 10 years old, it helps to understand the cost of different stages of a geothermal power project. It should be noted that the percentage of such costs may vary from country to country.

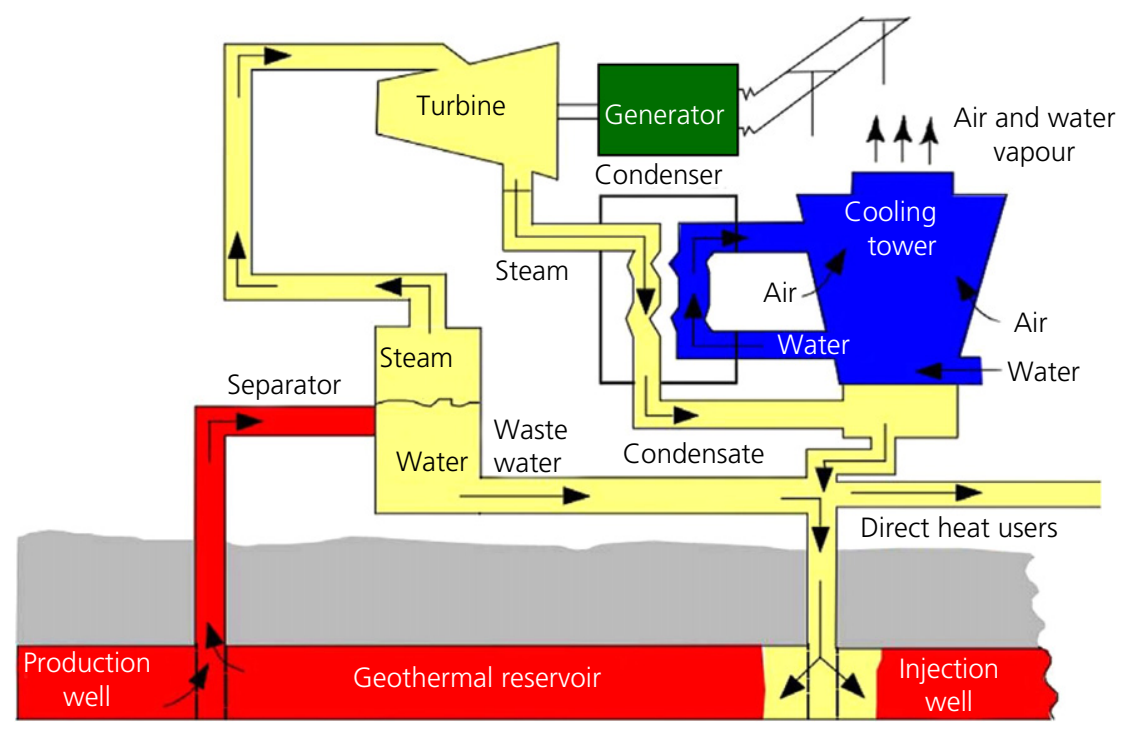

Figure 3. Flash steam geothermal power plant (GSE, 2011; Kagel, 2009; Lund, 2009)

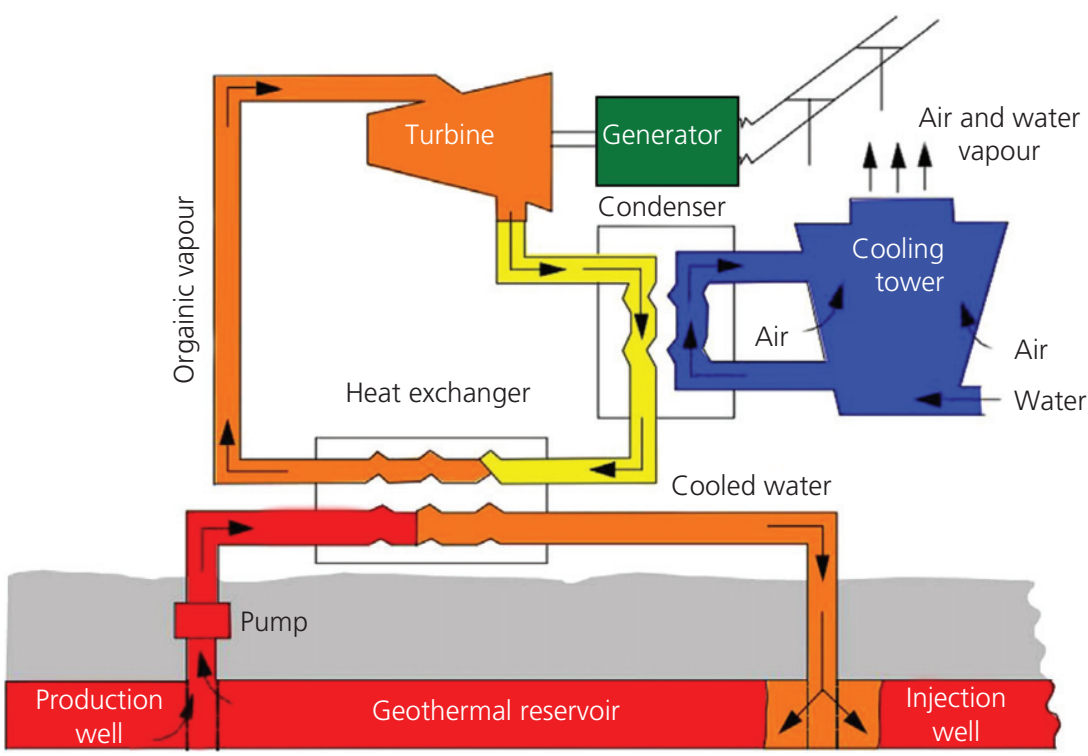

Figure 4. Binary cycle geothermal power plant (GSE, 2011; Kagel, 2009; Lund, 2009) 


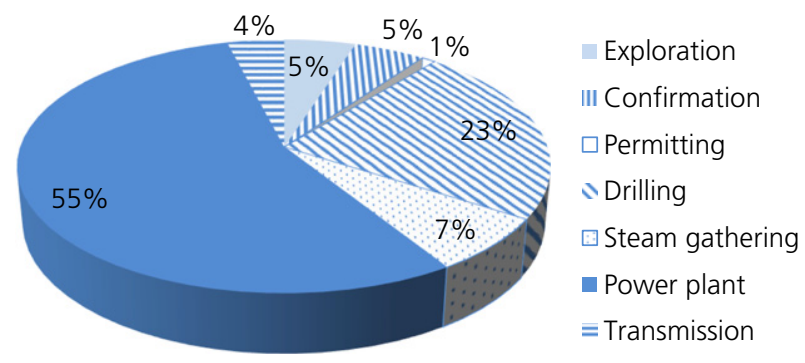

Figure 5. Typical cost breakdown of geothermal power projects (Hance, 2005)

\section{Geothermal resources in Oman}

The underground fluid temperature is the key element to be considered when evaluating the potential of geothermal energy for electricity generation and other uses. Knowing the temperature will further help to use the appropriate geothermal plant for energy generation. The temperature of Oman hot water springs is one of the main indicators that suggest that the temperature of underground fluid could be comparatively higher. According to the Oman Water Society (OWS, 2016), there are more than 360 water springs; most of which are in the Musandam, Muscat and Dhofar governorates and are non-traditional sources for fresh water. Of these, 23 springs are classified as hot water springs which are very famous for tourism and natural therapy. For instance, the temperature of the spring at $\mathrm{Al} \mathrm{Kasfah} \mathrm{(Figure} \mathrm{6),} \mathrm{located} \mathrm{in} \mathrm{Wilayt} \mathrm{Ar}$ Rustaq in the $\mathrm{Al}$ Batinah South governorate, is $45^{\circ} \mathrm{C}$ (MOT, 2016). In order to explore further the potential of underground temperature and to investigate the possibility of using geothermal energy in Oman, it was necessary to examine the fluid temperature at a certain depth in Oman. Such exploration required boring to obtain samples from the earth's interior and

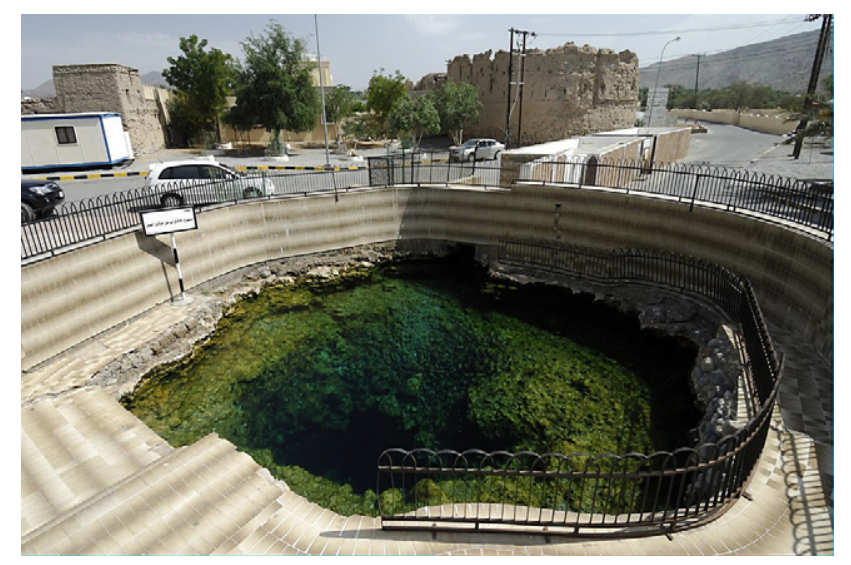

Figure 6. Al Kasfah Spring in Oman (MOT, 2016) to examine the temperature, and involved huge cost. The geothermal gradient can be used to estimate the depth of the desired temperature; however, as the thickness of the crust varies around the world, using an average value of geothermal gradient $\left(25^{\circ} \mathrm{C} / \mathrm{km}\right)$ would not give accurate results.

The only organisation which conducts underground exploration in Oman is the PDO. The main purpose of PDO exploration is to search for new oil and gas reserves; however, the measurement of sample temperature at a certain depth is part of such exploration. PDO operates more than 5000 well drillings in more than 120 oil fields in Oman. PDO is producing 7 barrels of well water per barrel of crude oil (5-6 million barrels of water a day). Most of the produced well water is reinjected into the same or new wells. The average temperature of the well water was estimated to be $86^{\circ} \mathrm{C}$ (AERO, 2008). The latest data obtained from PDO show significant temperatures (Table 2) at different locations in Oman, which could be used for energy generation. The 53 boreholes which have a temperature of more than $100^{\circ} \mathrm{C}$ are located in block 6 as shown in Figure 7.

Considering the temperature data of different boreholes in Table 2, the binary cycle geothermal power plant, which operates at a temperature of $85-175^{\circ} \mathrm{C}$, can be used for power generation. According to Monroy Parada (2013), binary power plants constitute $44 \%$ of total geothermal power plants in the world. A comparison of cost for electricity generation using different renewable sources is shown in Figure 8. It is clear that the cost of electricity generation from a geothermal binary plant is comparatively lower than that from solar, hydro, wind or nuclear plants. Electricity generation costs for a $50 \mathrm{MW}$ geothermal binary plant is US\$92/MWh (GEA, 2016). Such comparison provides a guideline to adopt an appropriate source of renewable energy in Oman. The maintenance of binary cycle power plants is highly influenced by different factors such as the nature of the geothermal fluid used in the primary loop, the nature of the working fluid, the technology and location of the plant, and the climate and weather. Corrosion and scaling are the most common problems in binary power plants (Monroy Parada, 2013).

\section{Conclusion}

The temperature data obtained from PDO for 53 boreholes indicate that there is potential for the utilisation of geothermal energy resources in Oman. Considering the temperature of these boreholes, the binary geothermal plant can be used to produce electricity. The cost of energy production of a binary geothermal plant is low compared with solar and wind. The initial cost of the geothermal project is high while the success of drilling is the main contributing factor. The maintenance of binary cycle power plants is highly influenced by different factors such as the nature of the geothermal fluid, the technology and the location 
Table 2. Temperature of 53 boreholes (temperature above $100^{\circ} \mathrm{C}$ )

\begin{tabular}{|c|c|}
\hline Well name & Temperature: ${ }^{\circ} \mathrm{C}$ \\
\hline Abu Thaylah & $102 \cdot 70$ \\
\hline Al Bashair & $157 \cdot 00$ \\
\hline Al Faisal & $116 \cdot 51$ \\
\hline Al Noor & $101 \cdot 40$ \\
\hline Ambrah & $100 \cdot 92$ \\
\hline Aseel & $100 \cdot 48$ \\
\hline Asfoor & $117 \cdot 74$ \\
\hline Barik & $124 \cdot 38$ \\
\hline Dafiq & $103 \cdot 00$ \\
\hline Faal & $120 \cdot 74$ \\
\hline Fahud South East & $163 \cdot 00$ \\
\hline Fahud South & $106 \cdot 60$ \\
\hline Fayrouz & $101 \cdot 63$ \\
\hline Inaam & $153 \cdot 84$ \\
\hline Khazzan I & $157 \cdot 65$ \\
\hline Khazzan II & $145 \cdot 74$ \\
\hline Lahan & $129 \cdot 64$ \\
\hline Mabrouk I & $121 \cdot 10$ \\
\hline Mabrouk II & $114 \cdot 40$ \\
\hline Makarem I & $173 \cdot 68$ \\
\hline Makarem II & $170 \cdot 00$ \\
\hline Musallim & $147 \cdot 54$ \\
\hline Nibras & $142 \cdot 84$ \\
\hline Qarn Nihayda & $110 \cdot 00$ \\
\hline Qashoob & $115 \cdot 40$ \\
\hline Rabab & $117 \cdot 00$ \\
\hline Sabeel & $114 \cdot 00$ \\
\hline Sakhiya & $107 \cdot 33$ \\
\hline Suwaihat & $106 \cdot 40$ \\
\hline Tibr & $140 \cdot 13$ \\
\hline Yibal I & $137 \cdot 20$ \\
\hline Yibal II & $123 \cdot 00$ \\
\hline Yibal III & $111 \cdot 00$ \\
\hline Yibal IV & $131 \cdot 10$ \\
\hline Zalzala & $107 \cdot 10$ \\
\hline Al Husain & $125 \cdot 00$ \\
\hline Al Huwaisah I & $126 \cdot 40$ \\
\hline Al Huwaisah II & $110 \cdot 00$ \\
\hline Al Huwaisah III & $114 \cdot 00$ \\
\hline Al Huwaisah IV & $124 \cdot 00$ \\
\hline Dhulaima I & $104 \cdot 00$ \\
\hline Dhulaima II & $157 \cdot 80$ \\
\hline Fahud & $130 \cdot 00$ \\
\hline Fushaigha & $110 \cdot 00$ \\
\hline Hasira I & $103 \cdot 30$ \\
\hline Hasira II & $103 \cdot 00$ \\
\hline Lekhwair I & $101 \cdot 70$ \\
\hline Lekhwair II & $160 \cdot 00$ \\
\hline Lekhwair III & $147 \cdot 00$ \\
\hline Saih Nihayda & 111.00 \\
\hline Saih Rawl I & $100 \cdot 60$ \\
\hline Saih Rawl II & $133 \cdot 00$ \\
\hline Shuwaiq I & $118 \cdot 90$ \\
\hline
\end{tabular}

of the plant, and the climate and weather. Other issues with binary geothermal plants are corrosion and scaling. In the GCC region, the United Arab Emirates has set a target to produce

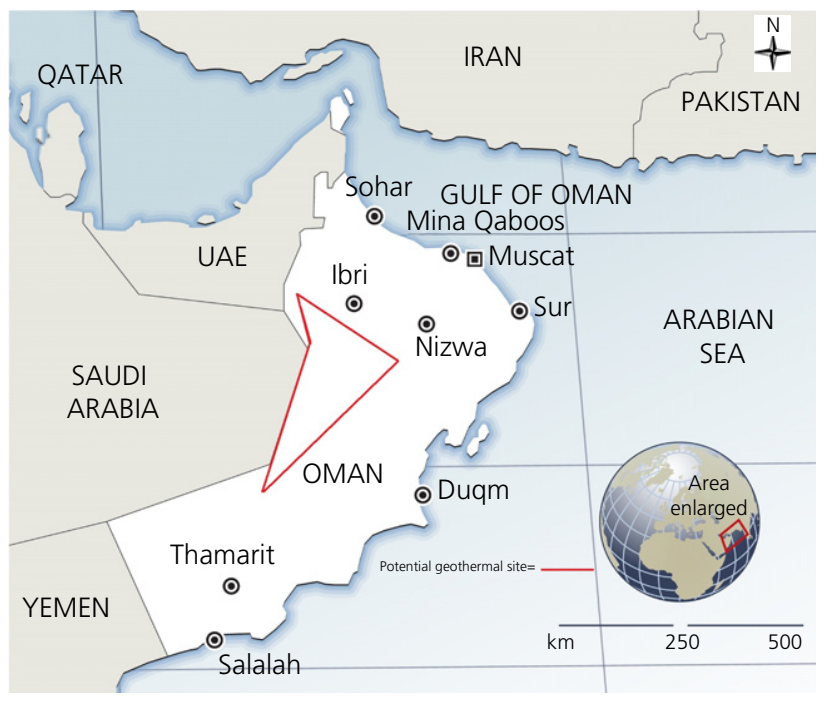

Figure 7. Location of boreholes with temperatures more than $100^{\circ} \mathrm{C}$

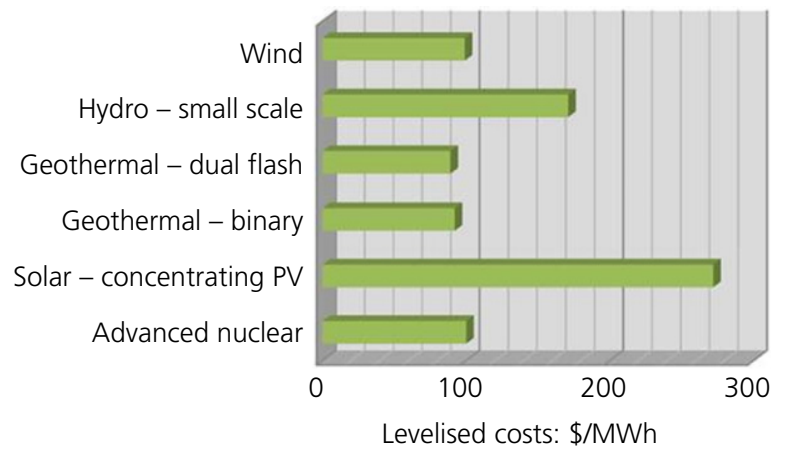

Figure 8. Electricity generation cost in US\$50/MWh from different renewable energy resources (GEA, 2016); $\mathrm{PV}$, photovoltaic

$25 \%$ of power by renewable sources by 2030 and Qatar aims to generate $20 \%$ of its energy from renewables by 2024 . The United Arab Emirates has recently started a feasibility study on the use of geothermal resources. There is an opportunity for Oman to consider geothermal energy resources and to reduce its dependency on oil and gas. This research is exploratory in nature and considers the temperature data for the potential use of geothermal resources in Oman. The data presented in this paper are from the PDO, keeping in mind that the focus of PDO is on oil and gas resources. The depth of the required temperature to use the geothermal resources will be a factor that will contribute towards the cost and needs to be considered during the feasibility study. While planning for using geothermal resources, Lund (2009) suggests that several associated 
environmental impacts such as emission of harmful gases, noise pollution, water use and quality, land use, and impacts on natural phenomena, wildlife and vegetation need to be considered.

\section{REFERENCES}

AERO (Authority for Electricity Regulation Oman) (2008) Study on Renewable Energy Resources. AERO, Muscat, Oman. See http://regulationbodyofknowledge.org/wp-content/uploads/ 2013/09/AuthorityforElectricityRegulation_Oman_Study_on.pdf (accessed 22/12/2016).

Alhamid MI, Daud Y, Surachman A et al. (2016) Potential of geothermal energy for electricity generation in Indonesia: a review. Renewable and Sustainable Energy Reviews 53: 733-740, https://doi.org/ 10.1016/j.rser.2015.09.032.

CBO (Central Bank of Oman) (2015) Annual Report 2014. CBO, Muscat, Oman.

Dickson MH and Fanelli M (2013) Geothermal Energy: Utilization and Technology. Routledge, Abingdon, UK.

DiPippo R (2012) Geothermal Power Plants: Principles, Applications, Case Studies and Environmental Impact. Butterworth-Heinemann, Oxford, UK.

Duffield WA and Sass JH (2003) Geothermal Energy: Clean Power from the Earth's Heat. Diane Publishing, Collingdale, PA, USA, vol. 1249.

Edrisi BH and Michaelides EE (2013) Effect of the working fluid on the optimum work of binary-flashing geothermal power plants. Energy 50: 389-394, https://doi.org/10.1016/j.energy.2012.10.025.

EPRI (Electric Power Research Institute) (2010) Geothermal Power. Issues, Technologies, and Opportunities for Research, Development, Demonstration, and Deployment. EPRI, Palo Alto, CA, USA.

GEA (Geothermal Energy Association) (2005) Factors Affecting Costs of Geothermal Power Development. GEA, Washington, DC, USA.

GEA (2016) Power Plant Cost. GEA, Washington, DC, USA. See http://geo-energy.org/geo_basics_plant_cost.aspx (accessed 22/12/2016).

Gehringer M and Loksha V (2012) Geothermal Handbook: Planning and Financing Power Generation. Energy Sector Management Assistance Program (ESMAP), World Bank, Washington, DC, USA.

GSE (Gestore Servize Energetici) (2011) Renewable Power Plants in Italy - GSE Statistical Report. GSE, Roma, Italy. See http://www.gse. it/it/Dati\%20e\%20Bilanci/GSE_Documenti/ENG/Italy $\% 20$ RES $\%$ 20Stastistical $\% 20$ Report $\% 202011 \% 20$ WEB $\% 20$ def $\% 2015-11$ 2012\%20\%20tag.pdf (accessed 21/12/2016).

Hance CN (2005) Factors Affecting Costs of Geothermal Power Development. Geothermal Energy Association for the US Department of Energy, Washington, DC, USA.

Holm A, Jennejohn D and Blodgett L (2012) Geothermal Energy and Greenhouse Gas Emissions. Geothermal Energy Association, Washington, DC, USA.

Kagel A (2009) The State of Geothermal Technology. Geothermal Energy Association, Washington, DC, USA.

Kaya E, Zarrouk SJ and O'Sullivan MJ (2011) Reinjection in geothermal fields: a review of worldwide experience. Renewable and Sustainable Energy Reviews 15(1): 47-68.

Kose R (2007) Geothermal energy potential for power generation in Turkey: a case study in Simav, Kutahya. Renewable and Sustainable Energy Reviews 11(3): 497-511.

Lee KC (2001) Classification of geothermal resources by exergy. Geothermics 30(4): 431-442.

Lund JW (2009) Utilisation of geothermal resources. Proceedings of the Institution of Civil Engineers - Energy 162(1): 3-12, https://doi. org/10.1680/ener.2009.162.1.3
Monroy Parada AF (2013) Geothermal Binary Cycle Power Plant Principles, Operation and Maintenance. United Nations University, Orkustofnun, Reykjavik, Iceland, Report Number 20. See http://os. is/gogn/unu-gtp-report/UNU-GTP-2013-20.pdf (accessed 22/12/2016).

MOT (Ministry of Tourism) (2016) Water Springs in Oman. MOT, Muscat, Oman. See http://www.omantourism.gov.om/ wps/portal/mot/tourism/oman/home/experiences/nature/springs/! ut/p/a0/04_Sj9CPykssy0xPLMnMz0vMAfGjzOItvc1dg40MzAzc A4OcDTyDQ4JNnP3CjM2cjPQLsh0VAaF1vGo!/ (accessed 22/12/2016).

Muffler P and Cataldi R (1978) Methods for regional assessment of geothermal resources. Geothermics 7(2-4): 53-89.

NCSI (National Center for Statistics and Information) (2008) The Development Experience and Investment Climate, 6th edn. NCSI, Muscat, Oman.

NCSI (2015) Statistical Year Book. NCSI, Muscat, Oman.

Ngangkham M, Ratha SK, Prasanna R et al. (2012) Biochemical modulation of growth, lipid quality and productivity in mixotrophic cultures of Chlorella sorokiniana. SpringerPlus 1: paper 33, http://dx.doi.org/10.1186/2193-1801-1-33.

OWS (Oman Water Society) (2016) Aflaj and Springs in Oman. OWS, Muscat, Oman. See http://www.omanws.org. om/en/page/aflaj_springs (accessed 23/12/2016).

Risch C and Eastham E (2012) Geothermal Energy: The Economics of West Virginia's EGS Potential. Center for Business and Economic Research, Marshal University, Huntington, WV, USA.

Shevenell L (2012) The estimated costs as a function of depth of geothermal development wells drilled in Nevada. GRC Transactions 36(2012): 121-128.

Sofyan Y (2012) Development of a new simple hydrostatic equilibrium model for sustainable evaluation in geothermal energy. Energy Procedia 14: 205-210, https://doi.org/10.1016/j.egypro.2011.12.918.

Umar T and Wamuziri S (2016) Conventional, wind and solar energy resources in Oman. Proceedings of the Institution of Civil Engineers - Energy 169(4): 143-147, https://doi.org/10.1680/jener.16.00011.

WB (World Bank) (2016) Data: Electric Power Consumption ( $k$ Wh per Capita). World Bank, Washington, DC, USA. See http://data. worldbank.org/indicator/EG.USE.ELEC.KH.PC?view=chart (accessed 10/08/2016).

Younas U, Khan B, Ali SM et al. (2016) Pakistan geothermal renewable energy potential for electric power generation: a survey. Renewable and Sustainable Energy Reviews 63: 398-413, https://doi.org/ 10.1016/j.rser.2016.04.038.

\section{How can you contribute?}

To discuss this paper, please email up to 500 words to the editor at journals@ice.org.uk. Your contribution will be forwarded to the author(s) for a reply and, if considered appropriate by the editorial board, it will be published as discussion in a future issue of the journal.

Proceedings journals rely entirely on contributions from the civil engineering profession (and allied disciplines). Information about how to submit your paper online is available at www.icevirtuallibrary.com/page/authors, where you will also find detailed author guidelines. 